Historic, Archive Document

Do not assume content reflects current scientific knowledge, policies, or practices. 



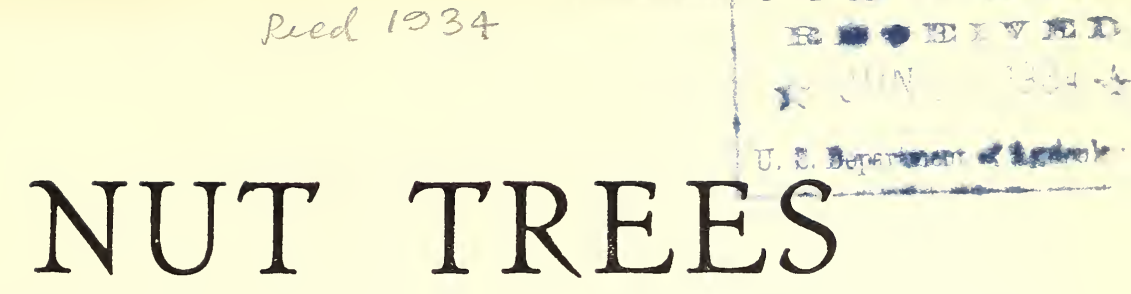

E. A. Riehl Farm

Amelia Riehl, Sec.
Nut Tree Nurseries

Godfrey, Illinois

$T_{\text {HE NUT INDUSTRY is growing in importance year by year. Nut }}^{\text {farming is certainly interesting as well as profitable. If it were }}$ possible to have it, almost everyone would take delight in the possession of a nut farm. It would be hard to think of a more fascinating heritage to leave children. We spend the whole of October each year in gathering and marketing nuts, and at the same time, PICK UP, with the nuts, health and happiness. Carefully look over our list of nursery stock. You may see something you want. Your order will have our very best attention. If you think of making a planting, call at our farm, if convenient, and look over our stock. You will see much on the place not listed here. We are a short distance off of Route No. 3, between Alton and Jerseyville-seven miles from Alton-fourteen from Jerseyville.

\section{BLACK WALNUTS}

THOMAS-The tree is a very thrifty grower, bearing early and abundantly. Nut large; kernel large and of excellent quality. It is a good cracker, ninety percent of the meat coming out in quarters and halves. This variety will crack out ten pounds to the bushel.

OHIO_A thin shelled nut of medium size and good quality. Its cracking qualities are also good. The tree is extremely hardy.

STABLER-Smaller than Thomas. It cracks even better than the Thomas-most of the kernels coming out in halves. Some of the nuts of this variety have but one lobe to the kernel. These crack out whole.

TEN EYCK-One of the "four old stand bys." Thinnest shelled of them all, and a nut of very fine quality.

STAMBAUGH-Won first prize in the 1926 contest staged by the Northern Nut Growers Association. (There were nearly 2000 entries in the contest). Stambaugh is an early and prolific bearer. Also the tree is an unusually fast grower.

ROHWER-Won second prize in the 1926 contest, and is also very highly recommended. 


\section{OUR SPECIALTY}

NEW WALNUTS-In the nation-wide search for better black walnuts, many interesting and very promising varities have been discovered, some scoring even higher than the old, standard varieties. We make a specialty of growing a few trees of each new variety that shows qualities of distinction. These are for sale to those who wish to help in the work of testing them and determining which are really the best varieties for commercial planting, and who have not facilities for the growing of their own trees. If interested in any new variety, write us. We may have it. If not, we can grow it for you.

\section{CHESTNUTS}

FULLER-Originated here. The tree is a fine grower and good bearer. The nuts are of good size, sweet, finely grained and delicately flavored. They can be kept in good condition longer than any other's. Miatures late mid-season. Worthy of extensive planting for commercial purposes, and fine for home use.

PROGRESS_-Same parentage as Fuller. Excellent in quality and a prolific bearer. Its blooming and fruiting season is the same as that of Fuller, which makes it a good one to plant with that variety for cross-pollination.

CHAMPION-Unsurpassed for vigor of growth, and an annual bearer. Nuts are light in color, good quality, and readily fall from the burr's.

VAN FLEET-Originated by E. A. Riehl, and named for his friend Dr. Walter Van Fleet. The name was given with Dr. Van Fleet's approval, while he was connected with the Bureau of Plant Industry at Washington D. C. This nut is a medium-early variety. One of the best in quality, vigor of growth and bearing habits.

GIBBENS-Earliest of all to ripen. About ten days earlier than any other known variety. The crop has ripened and been gathered as early as September 4th. The nuts are of medium size, very sweet and of a most beautiful chocolate color. Another of our choice seedlings worthy of propagation.

BOONE-A Japanese-American hybrid originated by the late Geo. W. Endicott. An early bearing and early ripening variety. The tree is abundantly productive of large nuts that sell readily in our mid-western cities. (New York prefers small chestnuts.)

EDWIN-A seedling of Boone. Similar to parent but ripens earlier.

DAN PATCH-Another Boone seedling. Ripens later than Boone. Nuts larger, and tree a better grower. 
RUSH CHINQUAPIN-Here we have a little nut that should be planted by everyone who has room for a tree. It is a small nut of highest excellence. Bears young and profusely. Often bears in nursery row eighteen months from the graft. Too small for commercial planting, but fine for home grounds.

\section{HICKORY HYBRIDS}

This class of trees is rapidly growing in popularity. Especially are they to be recommended for the landscaping of home grounds. The trees of all varieties are very beautiful and give sufficient shade for the average yard, not so dense, however, as to crowd out adjacent shrubbery. They adapt themselves easily to a great variety of soils and climatic conditions. Can be grown farther north than either the shagbark or the pure pecan. The interesting nuts of excellent quality add much to the attractiveness and value of these hybrids, sometimes called Hiccans. We have a limited number of these interesting trees ready for sale this season.

\section{THE WINKLER HAZEL}

This is by far the best of all the hazels and European Filberts which we have grown here experimentally. It bears regularly fine, large, well-filled nuts with the delicious flavor of the small wild hazel. The bush is well shaped, grows about six feet tall and colors beautifully in autumn; making it suitable for garden shrub or hedge screen for garage, etc. We offer well rooted plants for $50 \mathrm{c}$ each.

\section{PROPAGATING WOOD}

We are prepared to sell dormant graftwood of all varieties of Chestnut and Walnut named in the foregoing list for $10 \mathrm{c}$ per foot, delivered. For the hickories and some of the newest walnuts the price is $15 \mathrm{c}$ per foot.

\section{SAMPLE NUTS}

On receipt of $50 \mathrm{c}$ we will mail postpaid to any address in the United States a collection of sample chestnuts, or of the walnuts of which we have trees for sale.

\section{PRICES}

We grade our trees into only two sizes. Those of the small size averaging from $2 \frac{1}{2}$ to 4 feet in height. The large ones are anything above that, uip to 8 feet.

Large size trees $\$ 2.50$ each

Small size trees $\$ 2.00$ each

$\$ 25.00$ per dozen

$\$ 20.00$ per dozen

Hickories and the newest varieties of walnuts are $50 \mathrm{c}$ per tree higher. Write for special prices on large orders. 


\section{TERMS}

For immediate shipment-Cash with order. On orders booked for future delivery, fifty per cent cash with order; balance due when stock is ordered shipped.

\section{SHIPPING}

We prefer shipping by express, and, unless otherwise ordered, all tree shipments will be made in this way; not prepaid.

\section{GUARANTEE}

We make it a rule never to sell a tree that we do not feel sure would live and thrive if we planted it ourselves, and took care of it. Although we do not replace trees that die after leaving our hands, we guarantee trees to be true to name; also to be carefully dug, packed and delivered to transportation company in good condition.

\section{REFERENCES}

As to our reliability, we give as reference any officer of The Northern Nut Growers Association, of which organization we ourselves are members in good standing. Our financial rating can be ascertained through the First National Bank \& Trust Company, Alton, Illinois.

In answer to the question so often asked as to the hardiness of chestnut trees, we print the following letter, with the permission of Mr. Corsan.

Miss Amelia Riehl, The Riehl Farm,

The Kellogg Estate

Augusta, Mich., Nov. 15, 1927.

DEAR MISS RIEHL:

The chestnut trees I bought years ago from your father were Paragon, Parry, Progress, Fuller. They are growing well, being in fine condition and bearing nuts. They never winter killed, not even a bud. They are planted a few miles northwest of Toronto.

I do not know why more people in this country do not plant chestnut trees; for the native nut and the hybrids your father originated are so much sweeter and tastier than the European and Asiatic chestnuts. Sincerely yours, G. H. CORSAN.

Address all inquiries to Amelia Riehl, Secretary, E. A. RIEHL FARM, Godfrey, Illinois 